\title{
A SOLITARY WASP THAT PREYS UPON LACEWINGS (HYMENOPTERA: SPHECIDAE; NEUROPTERA: CHRYSOPIDAE)*
}

\author{
By Howard E. Evans \\ Department of Zoology and Entomology, \\ Colorado State University, Fort Collins, Colorado 80523
}

The tendency of solitary wasps to restrict predation to members of specific groups of arthropods is well known. There are several hundred records for diverse species of Bembix, for example, which suggest that all Northern Hemisphere species of this genus prey only upon Diptera. This includes 16 of the 19 species occurring north of Mexico; the remaining three have remained unstudied. Two of these, gillaspyi Evans and Matthews (1968) and frommeri Bohart (1970) were described only recently, while the third, stenebdoma Parker (1917) was described long ago but has remained one of the most infrequently encountered members of the genus. Although stenebdoma was placed in the belfragei species-group by Evans and Matthews (1968), largely on the basis of the partially preserved ocellar lenses, the species fits poorly in that group on most features and in fact is unique in the genus in having the first intercubital vein straight rather than angulated. Evidently this species is also unique in the genus, indeed among all digger wasps, in that the prey consists of lacewings (Chrysopidae).

The use of Neuroptera is not, however, unknown among Bembicini. Evans and Matthews (1973) presented a record of the Australian species Bembix wilcannia Evans and Matthews preying upon adult ant lions (Myrmeleontidae), and Alcock (1975) found Xerostictia longilabris Gillaspy preying upon adult ant lions as well as flatid buds in southern Arizona. Thus the record of Bembix stenebdoma using Chrysopidae seems less unusual than it would have seemed a few years ago. Why this species appears so rare when it has apparently entered a new and unexploited adaptive zone remains a mystery.

*Manuscript received by the editor October 10, 1978. 
My observations on B. stenebdoma involve a single female seen plunging into an open hole in a small draw $1.5 \mathrm{~km} \mathrm{SW}$ of Bernardo, Socorro Co., New Mexico, at 1000 hours on 2 August 1978. The soil in this area was coarse, stony, and hard, with sparse desert vegetation, but the draw was sandy and bordered by Croton plants which were in bloom and attracting many bees and wasps. Despite several hours of intensive collecting in this area by Kevin M. O'Neill and myself, we took no other specimens of B. stenebdoma.

This female was captured as she left the nest, and the nest was excavated. Burrow diameter was about $8 \mathrm{~mm}$, and there was no obvious mound of soil at the entrance. The burrow was straight and oblique, $30 \mathrm{~cm}$ long, terminating in a single cell at a vertical depth of $20 \mathrm{~cm}$. The cell was horizontal, $10 \mathrm{~mm}$ in diameter by $20 \mathrm{~mm}$ in length. It contained 10 paralyzed lacewings, all lying on their sides with their heads facing the entrance to the cell. The egg of the wasp had been laid on the side of one of the lacewings deep in the cell. The egg was elongate and curved, measuring $2.2 \mathrm{~mm}$ in length; it was

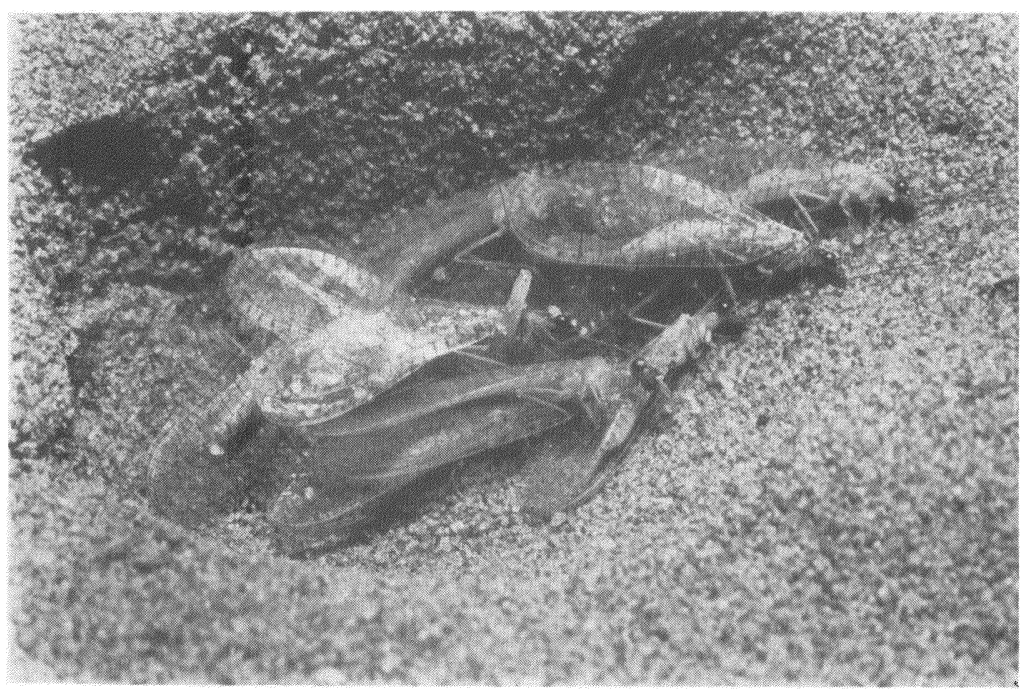

Figure 1. Prey and egg of Bembix stenebdoma. The cell contents have here been removed to an artificial cell and the lacewing bearing the egg moved to the top of the pile for purposes of photography. 
attached between the middle and hind coxae of the prey and extended over the wing base and well above the dorsum (Fig. 1).

This egg position is similar to that of many Bembix which prey upon flies. That there were 10 prey in the cell, with the female still provisioning, indicates that this species mass-provisions its cells. Mass provisioning is uncommon in Bembix, B. hinei Parker being the only other North American species for which this has been reported (Evans, 1957).

The lacewings proved to belong to three species: Eremochrysa tibialis Banks (2), E. punctinervis (McLachlan) (5), and Chrysoperla comanche (Banks) (3) (det. Phillip A. Adams). Dr. Adams writes that all three species are common in the Southwest. Although some Chrysopidae release odorous substances from thoracic glands, this is not notably true of members of these genera. It will be of interest to discover if $B$. stenebdoma consistently uses lacewings in other areas and whether predation is restricted to species of Eremochrysa and Chrysoperla.

\section{ACKNOWLEDGMENTS}

This paper is part of a study of the comparative behavior of solitary wasps, supported by the National Science Foundation, grant BNS76-09319. The assistance of Dr. Phillip A. Adams of California State University, Fullerton, in identifying the Chrysopidae is gratefully acknowledged.

\section{REFERENCES}

Alcock, J.

1975. The behavior of some bembicine wasps of southern Arizona (Hymenoptera: Sphecidae, Microbembex, Glenostictia, Xerostictia). Southwestern Nat. 20: 337-342.

BOHART, R. M.

1970. New species, synonymy and lectotype designations in North American Bembicini. Pan-Pac. Ent. 46: 201-207.

Evans, H. E.

1957. Studies on the Comparative Ethology of Digger Wasps of the Genus Bembix. Comstock Publ. Assoc., Ithaca, N.Y. 248 pp.

Evans, H. E., AND R. W. Matthews

1968. North American Bembix, a revised key and suggested grouping. Ann. Ent. Soc. Amer. 61: 1284-1299.

Evans, H. E., and R. W. MatThews

1973. Systematics and nesting behavior of Australian Bembix sand wasps. Mem. Amer. Ent. Inst., no. 20. 387 pp. 
PARKER, J. B.

1917. A revision of the bembicine wasps of America north of Mexico. Proc. U.S. Nat. Mus. 52: 1-155. 

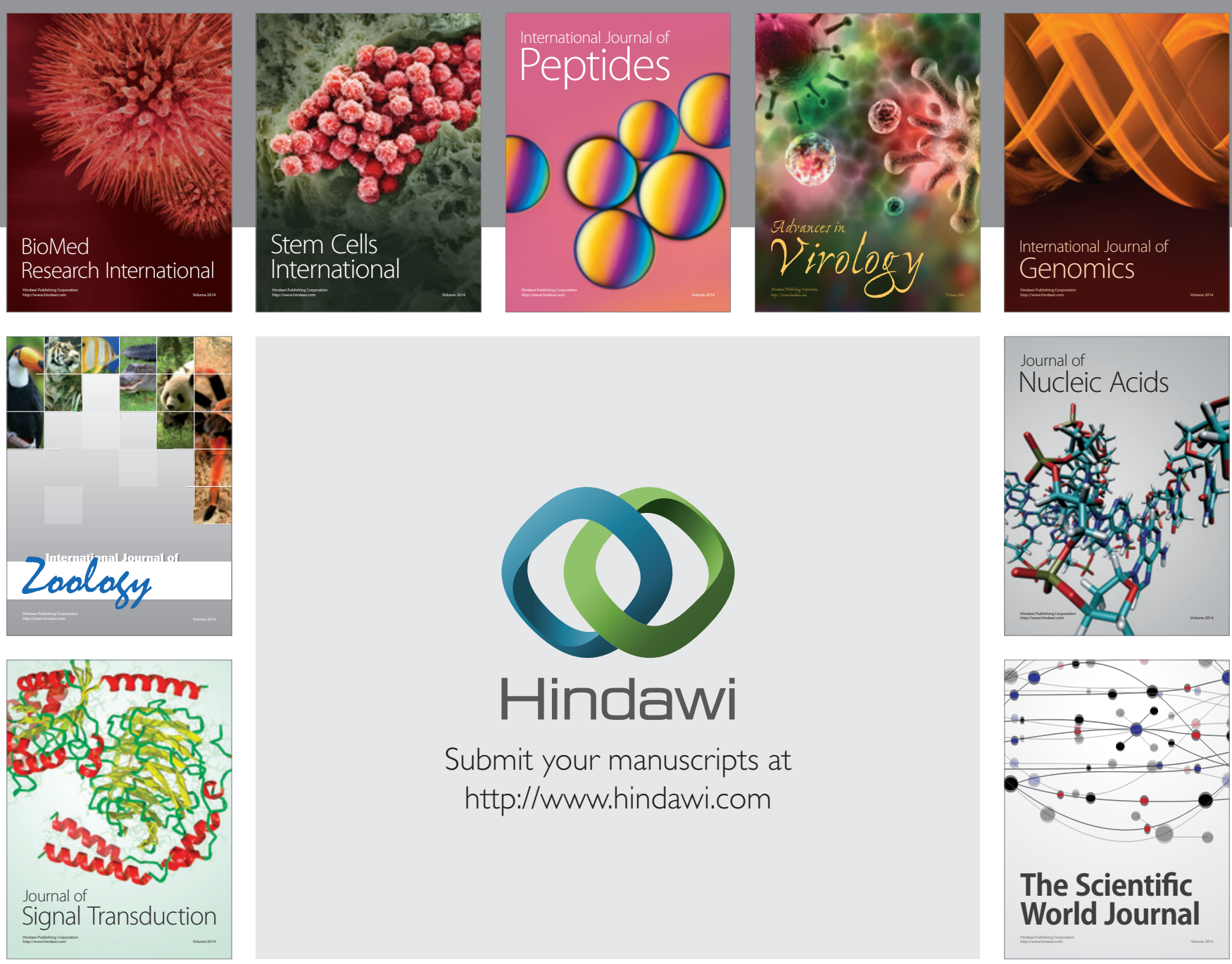

Submit your manuscripts at

http://www.hindawi.com
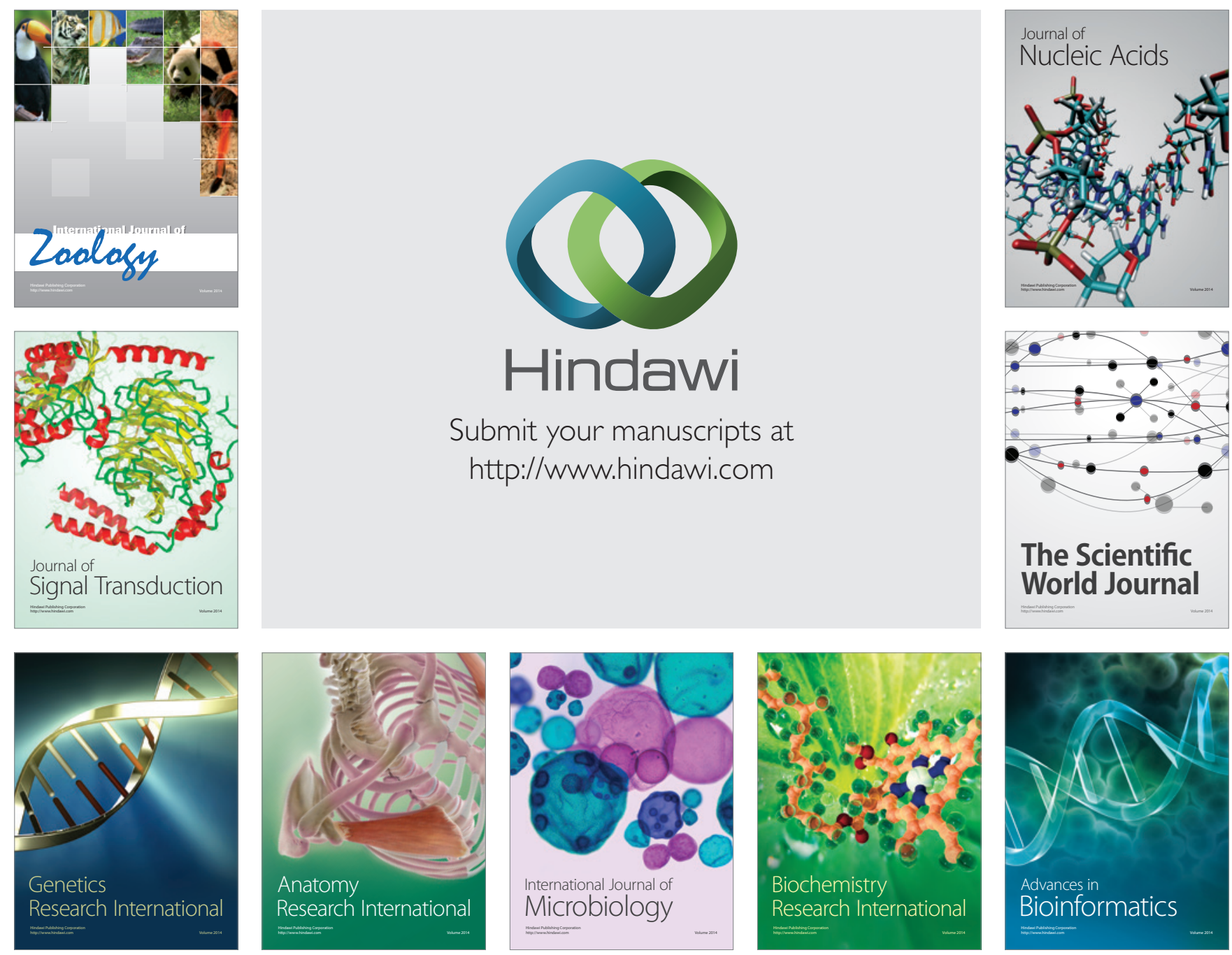

The Scientific World Journal
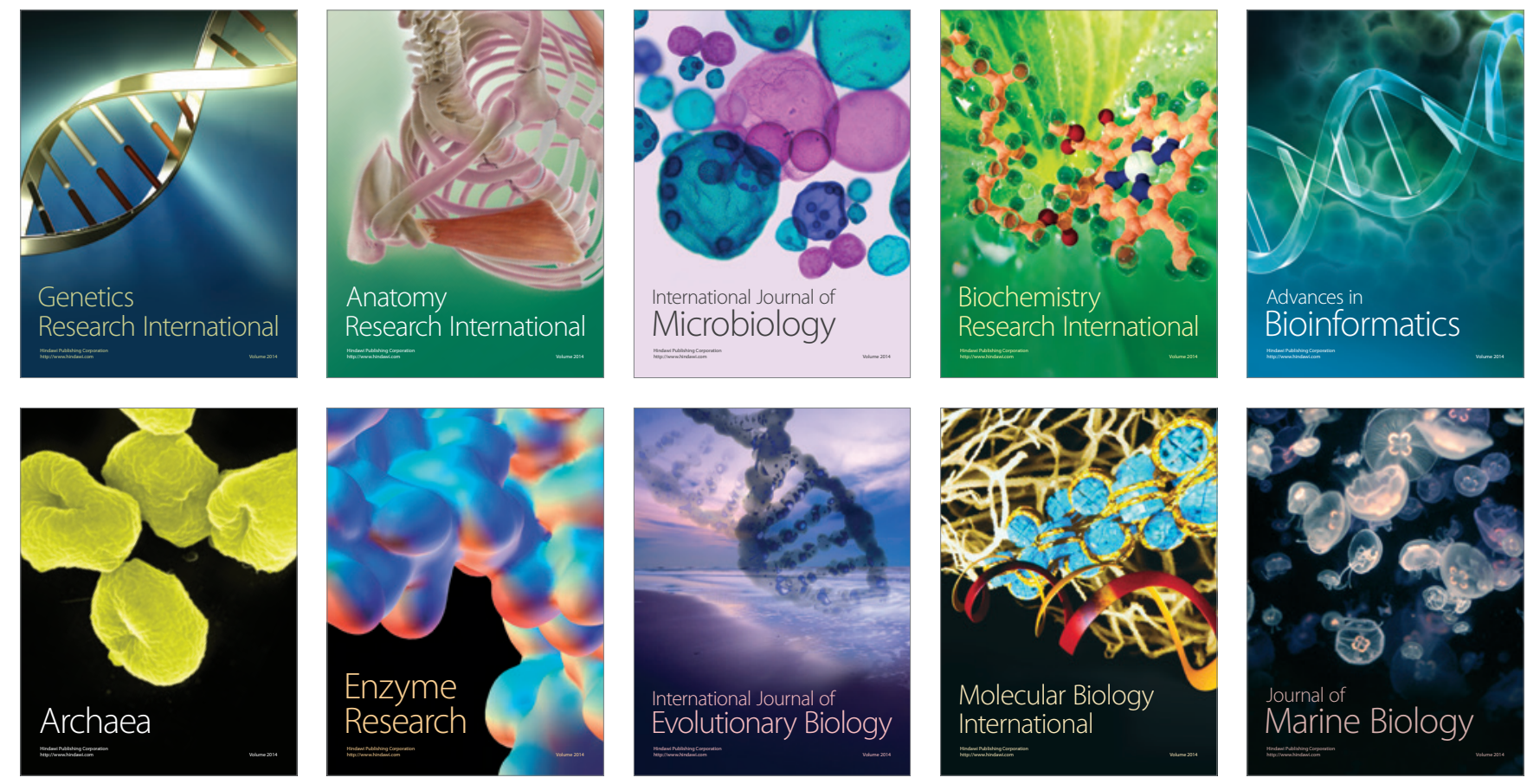